\title{
Soluble adenylate cyclase activity in Neurospora crassa
}

\author{
Juan A. REIG, Alberto R. KORNBLIHTT, Mirtha M. FLAWIÁ and Héctor N. TORRES \\ Instituto de Investigaciones Bioquímicas, 'Fundación Campomar' and Facultad de Ciencias Exactas y \\ Naturales, Obligado 2490, 1428 Buenos Aires, Argentina
}

(Received 26 March 1982/Accepted 18 June 1982)

\begin{abstract}
A soluble form of adenylate cyclase was extracted from mycelia of Neurospora crassa wild-type strains. This enzyme activity was purified by chromatography on hexylamino-Sepharose, agarose and Blue Sepharose and preparative polyacrylamide-gel electrophoresis. On sodium dodecyl sulphate/polyacrylamide-gel electrophoresis, peak fractions from the later purification steps showed a main polypeptide band with an apparent molecular weight of about 66000 . The following hydrodynamic and molecular parameters were established for the Neurospora soluble adenylate cyclase activity: sedimentation coefficient, $6.25 \mathrm{~S}$; Stokes radius, $7.3 \mathrm{~nm}$; partial specific volume, $0.74 \mathrm{ml} / \mathrm{g}$; molecular weight, 202000; frictional ratio, 1.65 . The isoelectric point of this enzyme activity was 4.65 . The enzyme was not activated by GTP, [ $\beta \gamma$-imido]GTP, fluoride or cholera toxin.
\end{abstract}

A membrane-bound adenylate cyclase activity [ATP pyrophosphate-lyase (cyclizing), EC 4.6.1.1] in the FGSC 1118 slime strain of Neurospora crassa has been described by workers in this laboratory (Flawia \& Torres, 1972a,b). In this mutant strain the characteristic polysaccharide wall of mycelial strains is absent. This adenylate cyclase activity has two interesting properties: first, it is $\mathrm{Mn}^{2+}$-dependent, the activity with $\mathrm{Mg}^{2+}$ being negligible; secondly, it is insensitive to fluoride (Flawiá \& Torres, $1972 a$ ). Such properties are also characteristic of other adenylate cyclases found in lower eukaryotic organisms, such as Mucor rouxii (Paveto et al., 1975), Saccharomyces cerevisiae (Varimo \& Londesborough, 1976), Trypanosoma cruzi (da Silveira et al., 1977) and Blastocladiella emmersoni (Lopez Gomez et al., 1978), as well as in cytosolic fractions of rat testicular germinal cells (Braun \& Dods, 1975; Neer, 1978; Kornblihtt et al., 1981).

The adenylate cyclase activity in Neurospora mycelial strains has not been studied in detail. Only two facts have been well established, namely the above-mentioned dependence on $\mathrm{Mn}^{2+}$ and the deficiency observed in strains carrying the $c r-1$ (crisp) mutation (Flawiá et al., 1977).

A better understanding of the function of adenylate cyclase activity associated with membranes from eukaryotic organisms requires some progress in the purification of this enzyme activity. Such progress, however, is hindered because of three main problems: the enzyme constitutes a small proportion of membrane protein; as an integral part of mem- branes, it requires detergents for solubilization; the enzyme activity is extremely unstable under reasonably mild conditions. In the case of soluble $\left(\mathrm{Mn}^{2+}\right.$ dependent) adenylate cyclase activity from testicular germinal cells, some success in the purification has been obtained in this laboratory by procedures that do not involve the use of detergents (Kornblihtt et al., 1981).

The present paper reports that a soluble form of adenylate cyclase can be extracted from the mycelia of wild-type Neurospora crassa strains. The purification and characterization of this non-sedimentable or 'soluble' adenylate cyclase activity are described.

\section{Experimental}

\section{Materials}

Phenylmethanesulphonyl fluoride, Pipes $(1,4-$ piperazinediethanesulphonic acid) and 1,6-diaminohexane were from Sigma Chemical Co. (St. Louis, MO, U.S.A.), Bio-Gel A-5 m was from Bio-Rad Laboratories (Richmond, CA, U.S.A.) and Trasylol was from Bayer (Leverkusen, West Germany). Sepharose 4B and Blue Sepharose CL-6B were purchased from Pharmacia (Uppsala, Sweden), and $o$-nitrophenyl $\beta$-D-glactoside was from Koch-Light Laboratories (Colnbrook, Bucks., U.K.). Hexylamino-Sepharose was prepared by the procedure of Cuatrecasas (1970).

The sources of other materials were as previously given elsewhere (Kornblihtt et al., 1981). 


\section{Strains and growth conditions}

Unless otherwise indicated, the original St.Lawrence 74 wild-type strain of Neurospora crassa from this laboratory's stock was used. Other wild-type strains, FGSC 987 (St.Lawrence), FGSC 2218 (Rockefeller-Lindegren), FGSC 1757 (Abbot) and FGSC 691 (Emerson), as well as the adenylate cyclase-deficient mutant FGSC 488 (cr-1) (Flawiá et al., 1977), were generously given by Dr. W. N. Ogata (Fungal Genetic Stock Center, Arcata, CA, U.S.A.).

Cultures were grown in Vogel's (1956) minimal medium containing $2 \%(\mathrm{w} / \mathrm{v})$ sucrose and $2.5 \mu \mathrm{g}$ of (+)-biotin $/ \mathrm{ml}$. Growth was at $30^{\circ} \mathrm{C}$ for $40 \mathrm{~h}$ with shaking $(120 \mathrm{rev} . / \mathrm{min})$ in $2000 \mathrm{ml}$ Erlenmeyer flasks containing $500 \mathrm{ml}$ of medium.

\section{Enzyme purification}

All operations were performed at $2-5^{\circ} \mathrm{C}$.

Step 1. Crude extract. Mycelia from wild-type strains were filtered on a Buchner funnel, rinsed with water, weighed and frozen with liquid $\mathrm{N}_{2}$. The material was ground in a mortar in the presence of liquid $\mathrm{N}_{2}$ and further homogenized with $2.0 \mathrm{ml} /$ wet wt. of mycelium of cold buffer A [ $50 \mathrm{mM}-\mathrm{Tris} / \mathrm{HCl}$ buffer, pH 7.5, containing 0.5 mM-EDTA, $1 \mathrm{~mm}$ dithiothreitol, $1 \mathrm{~mm}$-spermidine and $5 \%(\mathrm{v} / \mathrm{v})$ glycerol] containing $0.5 \mathrm{M}-\mathrm{NaCl}$ in an SDT Tissumizer (Teckmar Co., Cincinnati, OH, U.S.A.) provided with a $182 \mathrm{E}$ shaft and generator. This is a mechanical high-frequency dispersion apparatus whose generator recirculates the suspension. A rapid homogenization was obtained by the combined effects of shear, impact, collision and cavitation. Mycelial debris were discarded by centrifugation at $12000 \mathrm{~g}$ for $10 \mathrm{~min}$, and the supernatant fluid was further centrifuged at $105000 \mathrm{~g}$ for $120 \mathrm{~min}$. The supernatant fluid thus obtained was dialysed overnight against $40 \mathrm{vol}$. of buffer A. This dialysed preparation is referred to as 'crude extract'.

Step 2. Chromatography on hexylamino-Sepharose. The column $(3 \mathrm{~cm} \times 20 \mathrm{~cm})$, equilibrated with buffer A, was loaded with $1000 \mathrm{ml}$ of the crude extract (adenylate cyclase activity $14 \mathrm{pmol} / \mathrm{min}$ per $\mathrm{mg}$ of protein; $3 \mathrm{mg}$ of protein $/ \mathrm{ml}$ ). After a washing with about $500 \mathrm{ml}$ of this buffer solution, the column was eluted with $1000 \mathrm{ml}$ of a $0-0.7 \mathrm{M}-\mathrm{NaCl}$ linear gradient in the same buffer solution. Fractions $(25 \mathrm{ml})$ were collected at a rate of $2 \mathrm{ml} / \mathrm{min}$. Adenylate cyclase activity was eluted as a single nearly symmetrical peak, at about $0.37 \mathrm{M}-\mathrm{NaCl}$. Fractions corresponding to this peak, referred to as 'hexylamino-Sepharose fractions', were pooled, concentrated by ultrafiltration in an Amicon cell $(50 \mathrm{ml})$ provided with a PM-30 membrane and stored at $0-2^{\circ} \mathrm{C}$.

Step 3. Gel filtration. Pooled and concentrated hexylamino-Sepharose fractions $(7 \mathrm{ml} ; 25 \mathrm{mg}$ of protein $/ \mathrm{ml}$ ) were loaded on a Bio-Gel A-5 m (100 200 mesh) column $(2.5 \mathrm{~cm} \times 87 \mathrm{~cm})$ equilibrated with buffer A. Fractions (about $7 \mathrm{ml}$ ) were collected at a rate of $2.5 \mathrm{ml} / \mathrm{min}$. The fractions with the highest specific activity, referred to as 'Bio-Gel fractions', were combined and stored at $0-2^{\circ} \mathrm{C}$.

Steps 4 and $5 a$. Blue Sepharose chromatography steps. The column $(0.9 \mathrm{~cm} \times 15 \mathrm{~cm})$, equilibrated with buffer A, was loaded with $12-15 \mathrm{ml}$ of the Bio-Gel fractions $(1.5 \mathrm{mg}$ of protein $/ \mathrm{ml})$. After a washing with about $30 \mathrm{ml}$ of the equilibrium buffer, the column was eluted with a $0-0.8 \mathrm{M}-\mathrm{NaCl}$ linear gradient $(120 \mathrm{ml})$ in buffer A. Fractions $(5 \mathrm{ml})$ were collected at a rate of $1.5 \mathrm{ml} / \mathrm{min}$. Adenylate cyclase activity was eluted as a broad peak between $0.2 \mathrm{M}$ and $0.6 \mathrm{M}-\mathrm{NaCl}$. Fractions having the highest specific activity were immediately pooled, dialysed against buffer $\mathbf{A}$ for $3 \mathrm{~h}$ and loaded on the same Blue Sepharose column equilibrated with $20 \mathrm{~mm}-\mathrm{Tris} / \mathrm{HCl}$ buffer, pH7.5. The column was eluted with a $0-0.8 \mathrm{M}-\mathrm{NaCl}$ linear gradient $(100 \mathrm{ml})$ made in the latter buffer solution.

Step 5b. Preparative polyacrylamide-gel electrophoresis. Electrophoresis was performed for $10 \mathrm{~h}$ at $4^{\circ} \mathrm{C}$ on a Prep-Disc (Canalco) equipment, provided with a PD-2/70 upper column, by following the details given in the Instruction Manual and in accordance with the following conditions: stacking gel $(1.0 \mathrm{~cm}$ high), $3.5 \%(\mathrm{w} / \mathrm{v})$ acrylamide in $50 \mathrm{~mm}-$ Tris/ $\mathrm{HCl}$ buffer, $\mathrm{pH} 7.2$; separating gel $(4 \mathrm{~cm}$ high), $5 \%(\mathrm{w} / \mathrm{v})$ acrylamide in $0.37 \mathrm{M}$ - Tris $/ \mathrm{HCl}$ buffer, pH 8.4; electrode buffer, $30 \mathrm{~mm}$-Tris/glycine buffer, pH 8.2; elution buffer, $0.37 \mathrm{M}$-Tris $/ \mathrm{HCl}$ buffer, $\mathrm{pH} 8.4$, containing $10 \%(\mathrm{v} / \mathrm{v})$ glycerol; elution rate, $15 \mathrm{ml} / \mathrm{h}(2.5 \mathrm{ml}$ per fraction). Electrophoresis was performed at constant current $(10 \mathrm{~mA})$. The fractions from the first chromatography on Blue Sepharose that had the highest specific activity were concentrated by ultrafiltration on an Amicon PM-30 membrane; the sample $(1 \mathrm{ml})$ loaded on to the column contained $0.5 \mathrm{mg}$ of protein $/ \mathrm{ml}$.

\section{Determination of molecular and hydrodynamic parameters}

Enzyme sample. A $27 \mathrm{ml}$ portion of the crude extract was passed through a DEAE-cellulose column $(28 \mathrm{~cm} \times 2.5 \mathrm{~cm})$ equilibrated with buffer $A$. After a washing with about $200 \mathrm{ml}$ of this buffer, the column was eluted with a $0-0.5 \mathrm{M}-\mathrm{NaCl}$ linear gradient $(480 \mathrm{ml})$ in the same buffer. Adenylate cyclase activity was eluted as a single peak at about $0.27 \mathrm{M}-\mathrm{NaCl}$. Fractions having maximal adenylate cyclase activity, referred to as 'DEAE-cellulose fractions', were pooled $(40 \mathrm{ml})$ and precipitated by the addition of $17.2 \mathrm{ml}$ of a neutralized saturated $\left(\mathrm{NH}_{4}\right)_{2} \mathrm{SO}_{4}$ solution. After centrifugation, the supernatant fluid (1 vol.) was precipitated with $0.75 \mathrm{vol}$. of the saturated $\left(\mathrm{NH}_{4}\right)_{2} \mathrm{SO}_{4}$ solution. The pellet ob- 
tained after centrifugation was dissolved in about $1 \mathrm{ml}$ of buffer B (buffer A containing $0.15 \mathrm{M}-\mathrm{NaCl}$ ) and dialysed for $3 \mathrm{~h}$ against the same buffer solution. Samples of this enzyme preparation were used for centrifugation insucrose density gradients or for gel filtration as described below.

Sucrose-density-gradient centrifugation. Sedimentation studies were performed in $5-20 \%(w / v)$ sucrose linear gradients in buffer B made up in ${ }^{1} \mathrm{H}_{2} \mathrm{O}$ or ${ }^{2} \mathrm{H}_{2} \mathrm{O}$, by the procedure described elsewhere (Kornblihtt et al., 1981).

Gel filtration. A Bio-Gel A-5m (100-200 mesh) column $(0.9 \mathrm{~cm} \times 75 \mathrm{~cm}$; Glenco, precision bore $)$ was equilibrated and eluted with buffer $B$. Conditions were as follows: sample volume, $1.0 \mathrm{ml}$; flow rate, $2 \mathrm{ml} / \mathrm{min}$; temperature, $2-5^{\circ} \mathrm{C}$. The elution volume of each particular compound was expressed as the ratio of the elution volume of this substance to that of bacterial suspension $\left(K_{\mathrm{el}}\right)$.

Calibrating proteins. Calibrating proteins were added to the samples (gradient centrifugation or gel filtration) at the following concentrations: $\beta$-galactosidase (Escherichia coli), $50 \mu \mathrm{g} / \mathrm{ml}$; catalase (bovine liver), $100 \mu \mathrm{g} / \mathrm{ml}$; lactate dehydrogenase (rabbit muscle), $30 \mu \mathrm{g} / \mathrm{ml} ;$ malate dehydrogenase (pig heart), $10 \mu \mathrm{g} / \mathrm{ml}$; cytochrome $c$ (horse heart), $2 \mathrm{mg} /$ $\mathrm{ml}$. The void volume in Bio-Gel columns was determined by using a suspension of Rhizobium meliloti containing $6 \times 10^{8}$ bacteria $/ \mathrm{ml}$.

Calculation of molecular and hydrodynamic parameters. Calculations were performed as previously described (Kornblihtt et al., 1981).

Sodium dodecyl sulphate/polyacrylamide-gel elec- trophoresis. Electrophoresis was performed in gel slabs containing $10 \%(\mathrm{w} / \mathrm{v})$ acrylamide by the procedure described elsewhere (Kornblihtt et al., 1981). Gels were fixed and stained with an aqueous solution containing $25 \%(\mathrm{v} / \mathrm{v})$ methanol, $8 \%(\mathrm{v} / \mathrm{v})$ acetic acid and $0.2 \%$ Coomassie Brilliant Blue R250 and destained with an aqueous solution containing $25 \%(\mathrm{v} / \mathrm{v})$ methanol and $8 \%(\mathrm{v} / \mathrm{v})$ acetic acid. In some cases gels were restained with $\mathrm{AgNO}_{3}$ (Oakley et al., 1980).

\section{Enzyme assays}

Adenylate cyclase. Standard assays of adenylate cyclase activity were performed as previously described (Kornblihtt et al., 1981).

Other enzyme assays. Catalase, lactate dehydrogenase and malate dehydrogenase activities were assayed by the procedures described previously (Kornblihtt et al., 1981).

$\beta$-Galactosidase activity was measured at room temperature with $o$-nitrophenyl $\beta$-D-galactopyranoside as substrate, as described in the Worthington Enzyme Manual (Worthington Biochemical Corp., 1972).

\section{Other analytical procedures}

Isoelectric focusing of the hexylamino-Sepharose or Bio-Gel preparations was performed in an Ampholine (LKB, Stockholm, Sweden) pH range between 3.5 and 6.5 as previously described (Kornblihtt et al., 1981). Before electrophoresis, samples were dialysed against buffer $\mathrm{A}$ for $3 \mathrm{~h}$.

Table 1. Distribution of adenylate cyclase activity in fractions from Neurospora mycelial extracts

The freeze-dried mycelium (about $50 \mathrm{mg}$ ) was homogenized in $2 \mathrm{ml}$ of buffer $\mathrm{A}$ with or without $\mathrm{NaCl}(0.5 \mathrm{M})$, phenylmethanesulphonyl fluoride $(5 \mathrm{~mm})$ or Trasylol $(1000 \mathrm{units} / \mathrm{ml})$. Homogenates were centrifuged at $10000 \mathrm{~g}$ for $10 \mathrm{~min}$, and the supernatant fluids thus obtained were centrifuged at $105000 \mathrm{~g}$ for $60 \mathrm{~min}$. Fractions thus obtained were resuspended in the same buffer as that used during homogenization. Other conditions were as indicated in the Experimental section.

Additions to buffer A

None

$\mathrm{NaCl}(0.5 \mathrm{M})$

$\mathrm{NaCl}(0.5 \mathrm{M})+$ phenylmethanesulphonyl fluoride ( $5 \mathrm{~mm}$ )

$\mathrm{NaCl}(0.5 \mathrm{M})+$ Trasylol (1000 units $/ \mathrm{ml})$
Fraction

Homogenate

$10000 \mathrm{~g}$ sediment

$105000 \mathrm{~g}$ sediment

$105000 \mathrm{~g}$ supernatant

Homogenate

$10000 \mathrm{~g}$ sediment

$105000 \mathrm{~g}$ sediment

$105000 \mathrm{~g}$ supernatant

Homogenate

$10000 \mathrm{~g}$ sediment

$105000 \mathrm{~g}$ sediment

$105000 \mathrm{~g}$ supernatant

Homogenate

$10000 \mathrm{~g}$ sediment

$105000 \mathrm{~g}$ sediment

$105000 \mathrm{~g}$ supernatant
Total activity (pmol/min) 180

52

80

62

160

38

33

90

151

35

30

90

148

36

28

88
Specific activity ( $\mathrm{pmol} / \mathrm{min}$ per $\mathrm{mg}$ of protein) 
Details of other analytical procedures were also as given elsewhere (Kornblihtt et al., 1981).

\section{Results}

Existence of a 'non-sedimentable' form of adenylate cyclase in mycelial extracts

Mycelia from St.Lawrence 74 wild-type strain were homogenized in a $50 \mathrm{~mm}$-Tris buffer (buffer A) and the extract was subjected to two successive centrifugations. As shown in Table 1, one-third of the total adenylate cyclase activity was found in the $105000 \mathrm{~g}$ supernatant fluid. The proportion of this enzyme activity in the $105000 \mathrm{~g}$ supernatant was increased by up to $60 \%$ when $0.5 \mathrm{M}-\mathrm{NaCl}$ was included in the extraction buffer.

The possibility that a 'non-sedimentable' form of adenylate cyclase might arise after proteolysis of a membrane-bound enzyme could be discounted by the fact that the presence of two different proteinase inhibitors in the extracting buffer did not alter enzyme distribution (Table 1).

Similar evidence was obtained with mycelia from the other Neurospora wild-type strains FGSC 927, FGSC 2218, FGSC 1757 and FGSC 691. Percentages of adenylate cyclase activities found in the corresponding $105000 \mathrm{~g}$ supernatants, after homogenization with buffer $A$, varied from 20 to 40 . When these supernatant fractions were further centrifuged at $140000 \mathrm{~g}$ for $3 \mathrm{~h}$, adenylate cyclase activities remained in the supernatants. In addition, adenylate cyclase activity in all the fractions obtained from mycelia of the FGSC 488 strain was negligible. In this strain, carrying the $\mathrm{cr}-1$ (crisp) morphological mutation, mycelial concentrations of cyclic AMP were 10-fold or more lower than in wild type strains (Terenzi et al., 1976). Such evidence indicates that both 'membrane-bound' and 'non-sedimentable' or 'soluble' adenylate cyclase activities are affected to the same extent by a mutation at the $c r-1$ locus (results not shown).

\section{Comments on the purification of the Neurospora soluble adenylate cyclase}

Neurospora mycelia were extracted with a buffer solution containing $0.5 \mathrm{M}-\mathrm{NaCl}$, and the 'soluble' adenylate cyclase that remained in the $105000 \mathrm{~g}$ supernatant was subjected to purification procedures often employed with other soluble proteins.

Loss of enzyme activity was the major problem encountered during the purification of Neurospora adenylate cyclase. The best recovery of enzyme activity was obtained when spermidine, glycerol and dithiothreitol were present in the buffer solutions used. Because of this problem all purification steps had to be performed in less than 3 days. Maximal enzyme stability was obtained by storage at $2-4^{\circ} \mathrm{C}$.

During preliminary attempts to purify this enzyme
Table 2. Purification of the Neurospora soluble adenylate cyclase

For full details see the Experimental section.

\begin{tabular}{|c|c|c|c|}
\hline Fraction & $\begin{array}{l}\text { Protein } \\
\text { (mg) }\end{array}$ & $\begin{array}{c}\text { Total } \\
\text { activity } \\
\text { (pmol/min) }\end{array}$ & $\begin{array}{l}\text { Specific activity } \\
\text { (pmol/min per } \\
\mathrm{mg} \text { of protein) }\end{array}$ \\
\hline Crude extract & 3000 & 43000 & 14 \\
\hline $\begin{array}{l}\text { Hexylamino-Sepha- } \\
\text { rose fraction }\end{array}$ & 220 & 30000 & 136 \\
\hline Bio-Gel fraction & 20 & 12000 & 600 \\
\hline $\begin{array}{l}\text { 1st Blue Sepharose } \\
\text { fraction }\end{array}$ & 0.5 & 2700 & 5400 \\
\hline $\begin{array}{l}\text { 2nd Blue Sepharose } \\
\text { fraction }\end{array}$ & $<0.1$ & 1200 & 12000 \\
\hline
\end{tabular}

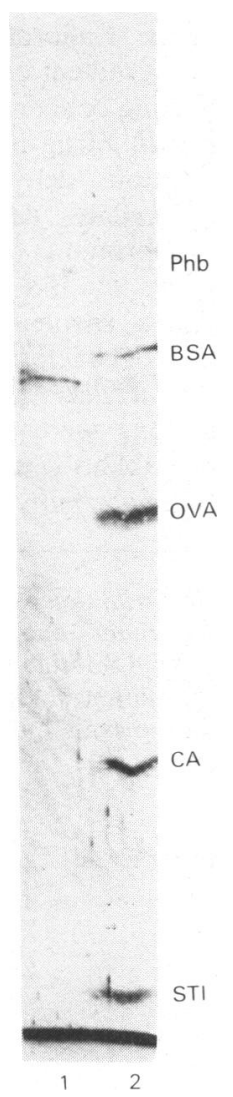

Fig. 1. Sodium dodecyl sulphate/polyacrylamide-gel electrophoresis of the peak fraction from the second Blue Sepharose column chromatography

1, Enzyme sample ( $<1 \mu \mathrm{g}$ of protein); 2, calibrating proteins (Phb, phosphorylase $b$; BSA, bovine serum albumin; OVA, ovalbumin; CA, carbonic anhydrase; STI, soya-bean trypsin inhibitor). The gel was stained with $\mathrm{AgNO}_{3}$. Conditions were as indicated in the Experimental section. 
activity DEAE-cellulose was used instead of hexylamino-Sepharose. However, the latter chromatographic support was eventually preferred because enzyme recovery and purification were better than those obtained with DEAE-cellulose.

Concentration of enzyme samples before gelpermeation chromatography was performed either by precipitation with $\left(\mathrm{NH}_{4}\right)_{2} \mathrm{SO}_{4}$ or by ultrafiltration. The latter procedure was preferred because enzyme recovery was much higher.

Conditions for adsorption of enzyme on Blue Sepharose varied from one preparation to another. Therefore in every case it was necessary to test for the optimum conditions. Although adsorption of enzyme on the support increased at lower $\mathrm{pH}$ values (e.g. $50 \mathrm{~mm}$-Pipes buffer, $\mathrm{pH} 6.5$ ), purification and recovery decreased when chromatography was performed at such $\mathrm{pH}$ values.

The overall recovery of enzyme activity after the second Blue Sepharose chromatography was about 2-3\%; alternatively the enzyme yield from the preparative disc electrophoresis was about $0.1-0.2 \%$ of the activity in crude extracts. After these purification steps, the amount of protein in the fractions showing adenylate cyclase activity was undetectable by the method of Lowry et al. (1951). A better evaluation of the protein concentration in the fractions was made in sodium dodecyl sulphate/polyacrylamide gels stained with $\mathrm{AgNO}_{3}$ (Oakley et al.. 1980). If it is assumed that enzyme protein (but not activity) was quantitatively recovered after these purifiction steps, the extent of purification of crude extracts would be about $10^{4}$-fold. Table 2 summarizes some of these results.

\section{Sodium dodecyl sulphate / polyacrylamide-gel electrophoresis}

On sodium dodecyl sulphate/polyacrylamide-gel electrophoresis, fractions having adenylate cyclase activity from the first or the second chromatography on Blue Sepharose showed several bands after staining with Coomassie Brilliant Blue R250 and $\mathrm{AgNO}_{3}$. The main band had a mobility slightly lower than that of bovine serum albumin (Fig. 1). This principal band was also observed in fractions having adenylate cyclase activity from the preparative gel electrophoresis (results not shown).

\section{Hydrodynamic and molecular characteristics of Neurospora adenylate cyclase}

Gel filtration. Fig. 2 shows the elution pattern of Neurospora adenylate cyclase from a Bio-Gel A-5 m column. $K_{\mathrm{el}}$ for adenylate cyclase was 1.8 , corresponding to a Stokes radius of $7.3 \mathrm{~nm}$ (inset).

Sucrose-density-gradient centrifugation. Results of the centrifugation of Neurospora adenylate cyclase through sucrose density gradients made in ${ }^{1} \mathrm{H}_{2} \mathrm{O}$ or ${ }^{2} \mathrm{H}_{2} \mathrm{O}$ are shown in Fig. 3. The sedimentation coefficients in both gradients had the same value, $6.25 \mathrm{~S}$ (inset), indicating that adenylate cyclase and the calibrating proteins have essentially the same partial specific volume, $0.74 \mathrm{ml} / \mathrm{g}$. The latter value is characteristic of globular 'soluble' proteins.

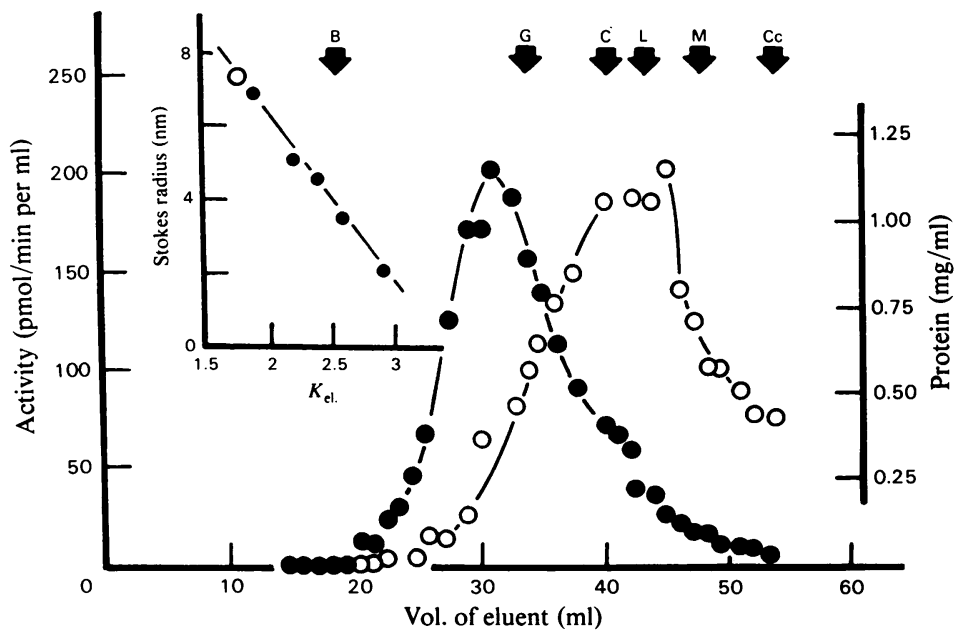

Fig. 2. Analytical Bio-Gel column chromatography of a Neurospora DEAE-cellulose preparation fractionated with $\left(\mathrm{NH}_{4}\right)_{2} \mathrm{SO}_{4}$

The inset shows the relationship between $K_{\text {el. }}$ and Stokes radii for calibrating proteins and cyclase. $\bullet$, Adenylate cyclase activity; $O$, protein. Conditions were as indicated in the Experimental section. Key: B, bacteria; G, $\beta$-galactosidase; $\mathrm{C}$, catalase; L, lactate dehydrogenase; $\mathrm{M}$, malate dehydrogenase; Cc, cytochrome $c$. 


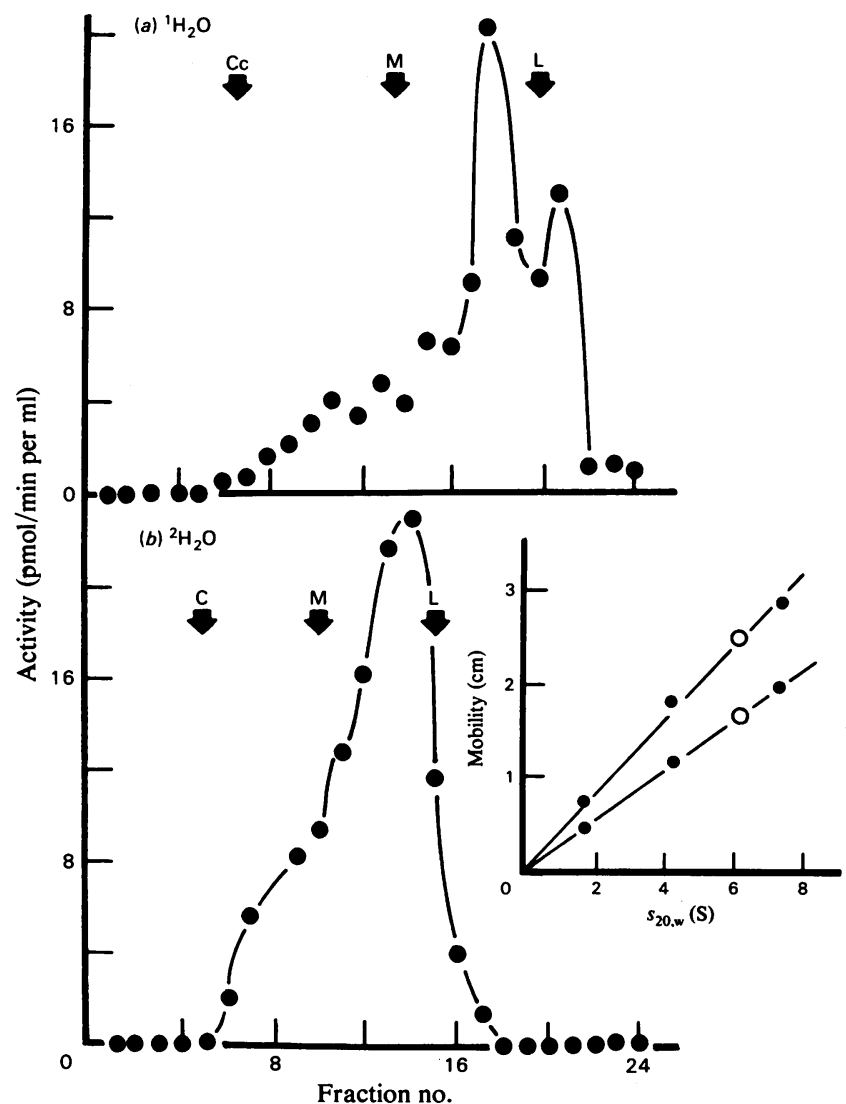

Fig. 3. Sucrose-density-gradient centrifugation of a Neurospora DEAE-cellulose preparation fractionated with $\left(\mathrm{NH}_{4}\right)_{2} \mathrm{SO}_{4}$

Gradients were made in ${ }^{1} \mathrm{H}_{2} \mathrm{O}(a)$ or ${ }^{2} \mathrm{H}_{2} \mathrm{O}(b)$. The inset shows the relationship between mobilities in the gradients and sedimentation coefficients for calibrating proteins and adenylate cyclase. Conditions were as indicated in the Experimental section. The key is as for Fig. 2.

Table 3. Hydrodynamic and molecular parameters of Neurospora soluble adenylate cyclase For full details see the text.

\section{Parameter}

Sedimentation coefficient (S)

Stokes radius $(\mathrm{nm})$

Partial specific volume $(\mathrm{ml} / \mathrm{g})$

Molecular weight

Axial ratio

Isoelectric point
Value

$6.2 \pm 0.1$

$7.3 \pm 0.05$

0.74

202000

1.65

4.6
Molecular parameters. Table 3 shows hydrodynamic and molecular parameters of Neurospora adenylate cyclase. Results are the average for at least six different experiments and enzyme preparations. From the experimental values a molecular weight of 202000 and a frictional ratio of 1.65 were calculated.
Isoelectric focusing. Enzyme activity was distributed between $\mathrm{pH} 4.5$ and 5 , with a main peak at pH4.6.

\section{Kinetic properties}

The activity of the Neurospora soluble adenylate cyclase in assay mixtures containing $\mathbf{M g}^{2+}$ instead of $\mathrm{Mn}^{2+}$ was negligible. In addition, fluoride, GTP and [ $\beta \gamma$-imido]GTP did not activate this enzyme. On the other hand, preincubation of a crude extract or other purified preparations of this adenylate cyclase with cholera toxin (pretreated or not with dithiothreitol) in the presence or absence of $\mathrm{NAD}^{+}$did not influence the activity (results not shown).

The behaviour of the soluble adenylate cyclase activity as a function of $\mathrm{Mn}^{2+}-\mathrm{ATP}$ or $\mathrm{Mn}^{2+}$ concentration was similar to that described for the membrane-associated enzyme (Flawiá \& Torres, 1972b). 


\section{Discussion}

The results indicate that Neurospora adenylate cyclase can be obtained as a soluble entity from an extract prepared with buffer solutions of high ionic strength. In addition, a simple procedure for purification of this soluble adenylate cyclase is reported. After the last purification steps enzyme fractions showed a main band with an apparent molecular weight of about 66000 . This value is similar to that reported for the soluble form of adenylate cyclase from rat testis (Kornblihtt et al., 1981).

Molecular and hydrodynamic properties of Neurospora soluble adenylate cyclase are strikingly similar to those reported for the catalytic subunit of this enzyme activity from lymphoma S-49 cells (Ross et al., 1978). It is noteworthy that Neurospora cyclase and the catalytic protein from an S-49 variant are dependent on $\mathrm{Mn}^{2+}$ and insensitive to fluoride and guanine nucleotides.

We express our gratitude to Dr. Luis F. Leloir for his advice and support and to our colleagues at the Instituto de Investigaciones Bioquimicas for helpful discussions and criticisms. This work was partially supported by the Consejo Nacional de Investigaciones Cientificas y Técnicas (CONICET), Argentina. M. M. F. and H. N. T. are Career Investigators of CONICET. A. R. K. is a Fellow of CONICET and J. A. R. is an Exchange Fellow between the Consejo Superior de Investigaciones Cientificas (Spain) and CONICET.

\section{References}

Braun, T. \& Dods, R. F. (1975) Proc. Natl. Acad. Sci. U.S.A. 72, 1097-1101

Cuatrecasas, P. (1970) J. Biol. Chem. 245, 3059-3065

da Silveira, F. J., Zingales, B. \& Coli, W. (1977) Biochim. Biophys. Acta 481, 722-733

Flawiá, M. M. \& Torres, H. N. (1972a) J. Biol. Chem. 247, 6873-6879

Flawiá, M. M. \& Torres, H. N. (1972b) J. Biol. Chem. 247, 6880-6883

Flawiá, M. M., Terenzi, H. F. \& Torres, H. N. (1977) Arch. Biochem. Biophys. 180, 334-342

Kornblihtt, A. R., Flawiá, M. M. \& Torres, H. N. (1981) Biochemistry 20, 1262-1267

Lopez Gomez, S., Mennucci, L. \& Da Costa Maia, J. C. (1978) Biochim. Biophys. Acta 541, 190-198

Lowry, O. H., Rosebrough, N. J., Farr, A. L. \& Randall, R. J. (1951) J. Biol. Chem. 193, 265-275

Neer, E. (1978) J. Biol. Chem. 253, 5808-5812

Oakley, B. R., Kirsch, D. R. \& Morris, N. R. (1980) Anal. Biochem. 105, 361-363

Paveto, C., Epstein, A. \& Passeron, S. (1975) Arch. Biochem. Biophys. 169, 449-457

Ross, E. M., Howlett, A. C., Ferguson, K. M. \& Gilman, A. G. (1978) J. Biol. Chem. 253, 6401-6412

Terenzi, H. F., Flawiá, M. M., Téllez-Iñón. M. T. \& Torres, H. N. (1976) J. Bacteriol. 126, 91-99

Varimo, K. \& Londesborough, J. (1976) Biochem. J. 159, 363-370

Vogel, H. J. (1956) Microbiol. Genet. Bull. 13, 4243

Worthington Biochemical Corp. (1972) Worthington Enzyme Manual, pp. 106-108, Worthington Biochemical Corp., Freehold 